\title{
From State Control to Competition: German Higher Education Transformed
}

\author{
ANDRÄ WOLTER \\ Dresden University of Technology and \\ Higher Education Information System (HIS), Hannover
}

\section{ABSTRACT}

Although there have been several cycles of debate and reform on higher education since World War II, the most recent proposals, some implemented and others under consideration, are by far the most far reaching and consequential of the period. Most aim at resolving the conflict between the ideal of the Humboldtian model of an elite research university, and the demand for an open, accessible, and differentiated system of higher education that takes into account the pivotal role of higher education in the modern world and in a democratic and pluralistic society. Forces and factors at work in other countries have affected the timing and dynamics of system transformation, but the unification in the early 1990 s of the two German states, in which higher education had very different structures and mandates, has played a great role in the matter. 


\section{RÉSUMÉ}

Les plusieurs cycles de débats et de réformes universitaires en Allemagne depuis 1945 se sont avérés modestes en comparaison avec les réformes actuelles, dont certaines sont déjà en vigueur tandis que d'autres sont à l'étude. La plupart des nouvelles réformes envisagent de résoudre la dissonance entre, d'une part, la vision humboldtienne de l'université d'élite où domine la recherche scientifique, et d'autre part, une insistance accrue sur l'acceptation des exigences de la modernité, de la démocratie et du pluralisme. Les forces et les facteurs observés dans d'autres pays industrialisés ont influencé la cadence et la dynamique des transformations allemandes mais en plus, la réunification des deux Allemagnes au début des années 1990 y est pour beaucoup. L'éducation post-secondaire dans les Allemagnes de l'Ouest et de l'Est fut différente en matière de structure et de mandat. L'unification s'avère un moteur de la réforme telle que vécue actuellement en Allemagne.

\section{INTRODUCTION}

In the early 1990s, a new wave of debate and activity in German higher education policy grew out of a deep crisis in that nation's universities. Players in higher education policy responded with a broad array of reforms at federal and state levels and within individual institutions.

There have been several cycles of debate and actual reform since World War II, but the last may be the most important of them. Almost every element of the German higher education system is in question, and reform projects of the last 10-15 years add up to a nearly complete renovation of German higher education.

Despite their often contentious and sometimes uncertain status, the sheer range of reform schemes is fundamental and make them a "transformation" rather a "reform" (Wolter, 1999). Transformation requires a bundle of reforms with systemic implications for the steering 
and governance of higher education. Further, transformation includes both intentional reforms and consequent latent processes of social change. This intersection of planned and unplanned changes produces unintended effects alongside desired results - together with unwanted or even counterproductive side-effects.

German higher education is in transformation partly due to accumulated pressures, which vary not only from state to state but between various higher education institutions and faculties. Transformation is more tolerated than promoted by universities, especially by academic staff. The primary players in reform are the German states (including the federal state) and university managers. Despite prevailing conceptions of institutional autonomy, the state continues to implement new kinds of institutional steering, rather than relinquish power and control.

\section{THE EVOLUTION OF THE MODERN GERMAN UNIVERSITY}

Higher education in Germany is often associated with Wilhelm von Humboldt's neo-humanistic or idealistic concept of the university. Indeed, the 19th century reform of German universities was to a considerable extent determined by notions formulated by Humboldt, Fichte, Schleiermacher, and other scholars in the early 19th century. Their arguments were crucial in transforming the corporative university system and its medieval features into the modern university, and producing the upturn in German scholarship and academic disciplines (Wissenschaft) of the late 19th and early 20th century (McClelland, 1980; Boockmann, 1999).

Drawing on Schleiermacher's theory, Humboldt formulated his idea of the university at the foundation of the University of Berlin in 1809. Most German universities adopted that idea in the first half of the 19th century (Schelsky, 1963; Turner, 1987), accepting a close connection between teaching and research, and treating students as near-equals in academic discourse. Research was to be the main function of the university, loosely tied to teaching. Bildung durch Wissenschaft-education (in the 
sense of personal development or cultivation) through academic studies (or scholarly life)-depended on research without specific occupational objectives. Philosophical faculties would be at the intellectual centre of the university, since philosophy unified all academic subjects. Meanwhile, the liberation of teaching and research from state control meant the state would be limited to funding the university, retaining control only of external academic affairs. There was to be autonomous self-government in all internal academic affairs.

German higher education became the model for higher education in many other countries. Yet even in late 19th-century Germany, a considerable gap between idea and reality was already apparent. Daniel Fallon (1980) sub-titled his famous book on the German university "a heroic ideal in conflict with the modern world." A small institution at the beginning of the century, the university slowly grew into a larger and more complex social entity with a correspondingly high degree of division of labour, through differentiation and specialization of academic disciplines. Jarausch (1991), among others, wrote of this transformation of a small pre-industrial academic enterprise into a large-scale academic enterprise of the industrial era.

A decisive factor in this change was, of course, the rise of the modern empirical sciences and of technical universities. But the German university clung to Humboldt's concept despite the contemporary realities of higher education. The political constitution of the university and its external relations remained under state control, but under the rule of Ordinarien, internally speaking. Between World War I and the end of World War II, new subjects of teaching and research multiplied without any serious structural change.

Especially between 1933 and 1945, the university ceased to be the liberal democratic institution designed by early university reformers. Instead, the German university became a stronghold of anti-democratic and anti-semitic political movements, partly during the Weimar Republic and particularly 
under National Socialism. After 1933 in many (perhaps most) universities, professors and students submitted more or less voluntarily to National Socialist policy. Totalitarian control and the racist and anti-intellectual policies of the "Third Reich" forced many academics to emigrate.

\section{HIGHER EDUCATION AFTER THE SECOND WORLD WAR}

Post-World War II, higher education was of course split between West and East Germany until re-unification in 1990. West German higher education was subjected to the authority of the Länder in accordance with the federal constitution, while a centrally-controlled system of higher education was established in the German Democratic Republic. For West Germany, the period 1945-1960 was primarily one of reconstruction and re-consolidation, taking up the old idea of the university and pre-1933 conditions, irrespective of evident gaps between idea and practice. Despite the creation of committees to encourage coordination and increased federal government funding and planning, higher education essentially stagnated.

Two main waves of reform and modernization debates and activities can be distinguished after 1960. An era of active higher education policy development started about 1968 and lasted until 1976. A still more lively reform wave began at the end of the 1980s. At first, this upturn was overshadowed by the re-structuring of East German higher education, carried out mainly by transferring by-then-obsolete institutional structures and regulations from West to East in the course of re-unification. But between 1993 and 1995, reform requirements and dynamics in German higher education policy became ever more pressing.

Beginning in the $50 \mathrm{~s}$, social demand for higher education accelerated (and has continued without significant interruptions to the present). Then in the 1960s and again in the late 1990s, concern grew that the German economy and labour market would require far more employees with academic qualifications than it had. Until 1980, expanding demand was met by the building of new universities and enlargement of older ones, with 
corresponding upgrades in the status of other post-secondary institutions. This educational expansion required internal modernization of the university and especially of the organization of studies. With universities now being large-scale organizations with as many as 30,000 to 50,000 members, traditional management and organization of studies seemed unprofessional and ineffective. But activist higher education policy could be implemented only if the federal and local states played their part.

\section{REFORM 1970-1976}

Until the end of the $1960 \mathrm{~s}$, the German states were exclusively responsible for legislation in higher education. The Federation had begun to fund higher education building and research in the 1950s. After amendments to the German constitution, co-operation between the federal level and the states began anew, and the Federation acquired responsibilities for framing education legislation, for planning, and for funding. In 1976, the higher education framework (Hochschulrahmengesetz) was passed at federal level, standardizing the structure and organization of higher education (later amended). State parliaments followed suit, and German higher education became strictly regulated by law at both levels.

The state's growing involvement coincided with widespread belief that higher education institutions lacked the strength or the will to make necessary reforms. Federal regulation was matched by detailed intervention at state level. Decrees and regulations carried law into daily practice on German campuses, and court decisions effected broad changes in admissions practice and labour relations.

About 30 new universities were founded to accommodate the vast increase in student numbers between 1960 and 1980. About 100 Polytechnics (Fachhochschulen) also appeared in this period, followed by comprehensive higher education centres (Gesamthochschulen), mostly themselves since turned into universities. Teacher training colleges became the nuclei of new universities. Technical universities became full universities. The

\section{The Canadian Journal of Higher Education}

Volume XXXIV, No. 3, 2004 
considerable regionalization of higher education provision reduced former regional disparities.

Equally significantly, between 1960 and 1980 new types of institution transformed German higher education into a two-tier system. Dedifferentiation in higher education has gone hand-in-hand with further differentiation. The most important measure was the introduction of a non-university sector through the foundation of Polytechnics (so-called Fachhochschulen), alongside the university sector and other institutions with equal status (such as colleges of arts). New institutional types are typically occupation-related, requiring shorter periods of study. The latter have been something of a success story: approximately one-third of all German students now enroll at such institutions. This binary structure has characterized the German higher education system since the early 1970 s.

There has also been reform of the political organization of the university. Until about 1970, full professors (Ordinarien) dominated the government of the university, together with "extraordinary" (associate) professors. During the so-called "1968" movement, students, nonacademic employees, lecturers, and other scholars without professorial status sought a share in academic self-government. The "group" university now relies on the participation of all member groups in varying proportions (parities), depending on the area of decision-making (teaching, research, appointments).

Academic programmes of study have been thought to be unduly prolonged, a problem further complicated by fluctuating enrolment (students switching subjects, drop-outs), insufficient differentiation in the provision and arrangement of subjects, and a lack of counselling facilities. In the 1970s supra-regional and local reforms in subject-matter areas led to new syllabi and examination regulations. Further, specialized courses of study were introduced for new academic fields, particularly in the Fachhochschulen. Responsibility for these activities lay with a network of study reform committees at federal or state level. Again, however, most 
of these changes were "passively endured rather than actively created" (Teichler, 1984, p. 12).

A radical break with German tradition was the introduction of admission restrictions. Higher education institutions had always been relatively open (except during the period of National Socialist higher education policy). But rapid enrolment growth in the late 1960s led to serious capacity problems and bottle-necks, first in such areas as medicine, but then in most subjects. Admission restrictions (Numerus clausus) were introduced for those "over-crowded" studies particularly in demand. There are several levels of restriction, local and national. A central institution was set up to carry out selection and allocation, the Centre for Allocation of Study Places (ZVS, Zentralstelle für die Vergabe von Studienplätzen) in Dortmund. Over the past two decades, criteria and procedures for selection and admission have changed several times. Still, except for eight to ten popular areas, most German university applicants are admitted to the university of their choice.

\section{MASSIFICATION WITHOUT ADAPTATION}

By 1978, the period of often controversial reform experiments seemed to be over. The founding of new higher education institutions and increases in academic hiring came to an end, primarily for budget reasons. The main task was now to cope with increased student demand caused by demographic growth and increasing attendance at German grammar schools (the upper-level secondary school whose final examination, the so-called Abitur, entitles a school-leaver to transfer to higher education). According to a 1978 agreement between federal and state governments, the main purpose of higher education policy and planning was to absorb growing social demand into existing institutions using current personnel and space capacity.

This meant a great shift in higher education policy. Growth and reform gave way to rationalizing and "improving" the effectiveness of higher 
education institutions. The "fat $70 \mathrm{~s}$ " were followed by the "lean $80 \mathrm{~s}$ " and the still "meager 90s." Political actors waited for better times to follow the anticipated decline in social demand in the early 1990s. But enrolment in the late 1980s did not decline as expected. At the end of the 1980s almost all non-governmental institutions of higher education policy-such as the Conference of the Rectors of German Universities or Academic Council (Wissenschaftsrat) - concluded that overload had not just led to problems in the quality and reputation of studies, but signalled the necessity of deeper reform in higher education.

The most important dynamic was the steady growth of student demand (Wolter, 1995). Some figures will illustrate the point. At the beginning of the 1950 s, the number of new students was 30,000 . This number grew to 280,000 in 1990 (an increase by a factor of nine), then dropped to 230,000 in 1995 (West Germany alone), only because of demographic factors, not because of changes in educational behaviour, aspirations, or decisions. In 2003, the number of new entrants in all Germany was 380,000. The number of new students, as a percentage of the age group, increased from $4 \%$ (in 1950) in some cycles, with periods of growth and some of stagnation, to $39 \%$ in 2003 . The total number of students has grown even more sharply. In 1950, the total number of students enrolled was 130,000; over 2 million are now registered. Further, the average period of study for the first degree has risen from four to more than six years.

Simple demand has thus influenced the development of higher education in Germany far more than any political reforms. Germany has turned from elite to mass higher education, but without taking necessary steps in management and organization of studies. Transformation has been caught in a conflict between modernization of function and conservatism of structure. American researchers on higher education, among them Burton Clark and Martin Trow, took the view that the strong quantitative growth"the shift in the conception of attendance from privilege to right" (Trow, 1974 , p. 76) - leads to a qualitative change to which the functions and 
structures of higher education must adapt. Expansion and differentiation are thus complementary tracks in the development of higher education (Clark, 1991; Trow, 1991).

In this regard, Trow criticized European higher education:

The history of European higher education since World War II has been the story of their efforts to grow in size and functions without radically transforming their institutional structures, and of the ensuing difficulties all European systems have encountered in trying to accommodate mass numbers and mass functions within structures designed for elite higher education (Trow, 1991, p. 165).

Perhaps Trow ignored or underestimated the diversity of European models of higher education (Teichler, 1990; Wasser, 1999), but on the whole, he was right about Germany.

Debates on reform lost direction in the course of political re-unification, which would have been, in any case, a conceptual and procedural challenge to higher education policy. Almost all efforts concentrated on the renewal and re-organization of the academic institutions in East Germany and their adaptation to West German standards. Meanwhile, West German universities were themselves caught up in a deep crisis of legitimacy. Some observers speak of a "reform jam" (Reformstau) over the past fifteen years.

\section{GERMAN HIGHER EDUCATION AT THE BEGINNING OF THE $90 \mathrm{~s}$}

About the middle of the 90 s, a new cycle of reform began, although no consensus had been found among all actors involved in the field of higher education policy. The following eight areas show the main problems or issues German higher education faced at the beginning of the $90 \mathrm{~s}$, before this new wave of reform debates and initiatives.

\section{(1) State power versus institutional autonomy}

External and internal affairs are subject to detailed state regulation, despite academic self-government on internal matters. There is a widespread belief that higher education has become entangled in a net 
of over-sophisticated laws and detailed administrative regulations, and that the state over-controls higher education through a proliferation of bureaucratic regulations and instruments (Brinckmann, 1998). On the other hand, there is an obvious inconsistency between a high degree of individual autonomy, within which professors enjoyed their academic freedom, and under-developed institutional responsibility. Both over-regulation and professorial independence may explain the institutional inertia of German universities until at least the 1990s.

\section{(2) Self-governance}

State dirigism, that is, the micro-management of universities by the Länder governments, has proved a mistake. But a deregulated or decentralized system will require many changes. Re-organization of relationships between state and higher education institutions demands that the internal steering and management procedures be improved and the power of university management strengthened. Professionalized management and accountability appropriate for large-scale organizations must be established at the faculty level. The older model of the group university has given way to the new concept of the managerial university, with a considerable shift in the balance of power from the traditional academic oligarchy to university management (Brinckmann, 1998; Mayer, Daniel, \& Teichler, 2003). Professors have naturally viewed these innovations with considerable scepticism.

\section{(3) Diversity and differentiation}

Debates provoked by educational expansion often emphasize diversity, with expansion and differentiation seen as two sides of the same coin. Vertical and horizontal diversification may take place at the system level, with differentiation between different types of institutions, or at the institutional level, with differentiation between individual institutions of the same type (often called profiling), and at the programme level in the provision and organization of studies. 
Diversification is seen as a response to the more heterogeneous composition of the student body. Growth in the higher education sector cannot simply mean more of the same. As stated in an OECD-report on tertiary education in Germany from 1997:

The Humboldtian idea of a university in practice valued research above teaching. It was a university type ideal for an elite higher education system.... But in a mass higher education system, different forms of teaching and learning and different forms of institutions are needed to satisfy a much greater demand for a variety of graduates (OECD, 1997, p. 18).

Germany differentiates clearly only between universities and the nonuniversity sector of the Fachhochschulen. In a few states, Berufsakademien (non-academic colleges) are a hybrid combining academic study with vocational training. The much larger university sector is fairly homogeneous in formal status and are regarded as roughly equal in quality. Distinctions in reputation apply more to research, than to teaching. The German university ideal remains the "full university" with a broad range of subjects; but practice and ideal rarely coincide.

\section{(4) Competition}

Standardization and weak differentiation imply that competition may be under-developed in German higher education. There is certainly competition between professors, but less between institutions, except in staff recruitment. Expert commentators believe the introduction of competition and market-orientation principles would raise the quality, effectiveness, and international attractiveness of German higher education. There might be competition between universities and faculties for student and staff recruitment, academic reputation, or funding. Professors and students might compete for appointment or admission, respectively, to a university with a good or better reputation. 


\section{(5) Innovation}

During the $80 \mathrm{~s}$ and early $90 \mathrm{~s}$, differentiation and specialization of academic programmes increased substantially. The most important institutional and curricular differentiation is between studies in the university sector and studies in the Fachhochschul sector. Basically, German universities prepare students for professional employment, as well as for research activities in a uniform system of study. Except for the differentiation between universities and Fachhochschulen, there is no strict separation between advanced studies for research training, and such studies primarily oriented towards the acquisition of professional skills.

There is very little differentiation in terms of duration, degrees, or objectives. The prevailing mode is full-time, on-site study for the compulsory nine or ten terms (in reality much longer). Courses of study are organized as continuously progressive, subject-specific programmes. Even ten years ago, any consecutive differentiation between undergraduate and graduate studies, with corresponding degrees (Bachelor's and Master's) and a credit point accumulation and transfer procedure was unusual. Prolonged studies and a high drop-out-rate have become endemic.

\section{(6) Quality assessment}

At the beginning of the 1990 s, quality assessment became a very new topic in German higher education policy. According to Humboldt's traditional idea of research and teaching as a unit, good research produces high-quality teaching. The university focussed primarily on research as the base of the academic career system, and teaching was often under-valued, particularly in the professional attitudes of the academic staff. Many observers argued that the quality of teaching lagged far behind the quality of research. There was no tradition of teaching evaluation. The introduction of a quality assessment and management system, emphasizing teaching, was a far-reaching innovation. 


\section{(7) Internationalization}

Among member states of the European Union, Germany has a high degree of exchange and mobility in both directions. However, in the 1990s, serious concern was raised over the decline in numbers and proportion of foreign students as an indicator of the decreasing international reputation and attractiveness of German higher education institutions. There has been also a strong brain drain of academics from Germany to North American universities. Complaints about the low level of foreign mobility were based primarily on the observation that internationally mobile students from the Asian-Pacific Area or North America preferred other European countries. This was blamed on the internationally non-compatible organization of studies in Germany and the length of required studies, in addition to difficulties with the German language or the strict legal status of foreigners in Germany.

\section{(8) Stagnation of resources}

The deep crisis in German higher education was characterized as a matter of overcrowding, under-staffing, and under-funding. Since 1975, there has been an increasing discrepancy between investment in the infrastructure of higher education and continuing enrollment growth. Staff numbers, the ratio of academic staff to students, the available number of study places, and the total funding for higher education illustrate the difficulty. The proportion of students per professor was 36.7 in 1980, and presently is 51.2.

Because the private sector in German higher education is small, the ratio of public expenditure for higher education to the gross domestic product is a fairly reliable indicator. This index increased to 1975's maximum of 1.3, then decreased, reaching a minimum in 1990 of 1.0. After 1992, there was a small increase caused primarily by the restructuring of higher education in East Germany; and this indicator levelled off to about 1.1 in 1999. According to OECD statistics (OECD, 2003), expenditure for tertiary education per student in the year 2000 (in $\$$ US) was $\$ 20,358$ in the US, 
$\$ 14,983$ in Canada, but only $\$ 10,898$ in Germany. Expenditure for tertiary education as a proportion of the gross domestic product in 2000 was $1.0 \%$ in Germany, $2.6 \%$ in Canada, and $2.7 \%$ in the US.

\section{A NEW REFORM POLICY}

In an international comparison, Germany may be an example of a "delayed nation" (a term coined by Helmuth Plessner) finally reforming higher education. Federal higher education frame law and all state laws have been amended several times during the last decade, or will be amended in the near future. In the past, reform flowed primarily from the state to higher education institutions. Few universities wanted to be seen as "reform universities." Particularly in the 1970s, reform of higher education was seen as a left-wing project whose key demands were the "opening up" and "democratization" of higher education. Today, the main paradigms are those of academic capitalism and the managerial university. Many institutions try to lead the way by implementing their own projects, sometimes in accordance with state regulations and legislation, sometimes going ahead with pilot projects. A new pattern of innovation has become part of the institutional policy of many German universities, among them some formerly rather conservative institutions and, conspicuously, many technical universities.

To a certain extent, a new spirit of reform competition has evolved among German higher education institutions. One measure of change is that some well-known foundations now offer rewards to universities for reform activities. But the major impetus for change has been severe cuts in public funding, as a result of the massive crisis in public finances. In most German states, including the prosperous ones, a policy of reducing capacities and resources is carried out, and states are closing courses of study, faculties, smaller institutions, and merging whole universities. Institutions are expected to achieve more with less. All of this is legitimized through new procedures of accountability and evaluation and improved 
efficiency through internal rationalization. Thus institutions have been forced to behave more strategically and become more market-oriented in search of new sources of revenue. German higher education is now passing through the first stage of a longer process, which will probably lead to the transformation of a public, non-profit system into a mixture of public/ private, partly profit-oriented, mostly not really for-profit, but at least fundraising oriented organizations.

\section{THE NEW STEERING MODEL}

Some reforms are inspired by the concept of new public management: the (mostly moderate) transfer of business management steering models to public institutions and organizations (Brueggemeier, 2001; Mey, 2001). In Germany this is called the new steering model ("Neues Steuerungsmodell').

\section{(1) Private institutions}

In 2000 , there were 350 separate higher education institutions in Germany. Traditionally, a small sector of about 40 private higher education institutions were run by the churches, concentrating mainly on theology and social work, and teaching less than $1 \%$ of the student population. Over the last decade, the number of private institutions has doubled: there are now 30 with university status, and 50 in the sector of Fachhochschulen, in most cases non-denominational. These new private institutions are highly selective, charging high (sometime exorbitant) tuition fees. They specialize in occupation-related studies rather than research, and most concentrate on business or computer studies, with close ties to specific companies or other economic organizations. There are two significant exceptions: the University of Witten-Herdecke, which offers medicine, and the International University of Bremen, which provides a broader range of subjects; both are largely state-funded. Co-operating closely with industry and offering excellent employment prospects, this new private sector exerts considerable pressure on state higher education institutions.

The Canadian Journal of Higher Education

Volume XXXIV, No. 3, 2004 


\section{(2) New forms of legalizing and maintaining institutions}

Another way to reduce excessive state control on higher education was opened up by a 1998 amendment to the higher education law, providing the opportunity to organize higher education institutions on a different legal basis. Traditionally, institutions had a double legal status as independent public corporations and as state institutions. The state has primary responsibility for budgets, staff, buildings, and in the last instance, courses of studies and degrees. Institutions act as representatives of the state within the scope set up by state regulation. Institutions under private maintenance have needed state recognition for degrees offered. Now institutions can be established as public foundations, or converted to such (Palandt, 2002a). This is not privatization, because the institutions remain public corporations primarily supported by the state, but it does give institutions a larger degree of independence. Lower Saxony (Niedersachsen) is the first German state where institutions have been re-organized as foundations with their own capital base and a larger degree of autonomy in economic affairs, under new strategic kinds of state regulation and internal governance. Certain radical reformers have proposed to go further, converting universities into stock companies, but this direction has garnered no support.

\section{(3) New procedures of steering}

German higher education has been characterized by a mixture of directive and consensual steering: directive with regard to the relationships between the state and the institution, consensual with regard to internal co-ordination. Both these patterns of steering have reached their limits, leading on the one hand to over-regulated institutions and an overtaxed state, and on the other hand to a lack of effectiveness within the institutions. During the last few years, a new concept has been adopted by some German states and institutions: the so-called "new model of steering." Three ideas (Braun \& Merrien, 1999; Brinckmann, 1998; Luethje, 2002; Luethje \& Nickel, 2003; Palandt, 2002b; Mayer, Daniel, \& Teichler, 2003) sustain 
the model: a shift from direct, more or less hierarchically executed state control to contractual kinds of steering; a shift from dirigiste state control to a kind of "global" steering, which limits the responsibilities of the state only to the strategic objectives, and to the legal and financial basis of higher education development; and a shift from ex-ante or input steering to expost or output steering, with outcomes and effectiveness playing a decisive role in allocation and regulation procedures.

These new instruments of steering do not end general state responsibility for higher education, but de-centralize and diminish it. The objective is a new balance between the state and the university (and between the university management and the academic oligarchy) through such procedures as:

- so-called "Hochschulpakte"-pacts or contracts between state and institutions on the medium-term determination of budgets, development plans, institutional structures, and provisions;

- so-called "Ziel- or Leistungsvereinbarungen" - target- or performance-oriented negotiations and agreements that specify strategic targets of further development, reforms, and other activities, often combined with allocation decisions (financial incentives or sanctions);

- new kinds of control, evaluation, and accountability at each level of institutional autonomy and responsibility;

- new procedures of budget allocation and distribution;

- strengthening the responsibilities and professionalization of the university management at both levels, the central and the de-central faculty level (deans), in budgeting as well as in study reforms, quality assessment, and development planning; and

- introduction of so-called "Hochschurätel" or "Kuratorien"- external councils or boards, with both advisory and far-reaching decisionmaking functions in funding, personnel, and development issues.

There is no common or standard practice among the 16 German states concerning the implementation of these new forms of steering, but rather a colourful combination of different elements and procedures specific to each state. A radical cutback of state control of higher education in favour of an extensive institutional autonomy is improbable. Rather, there will be 
various kinds of co-operation and interconnection between state and higher education institutions and, overall, institutions will have more decisionmaking power, modified by buffer institutions - boards, evaluation and accreditation agencies, or expert committees.

\section{(4) Funding and allocation}

This comprehensive de-regulation necessitates flexible budgeting and allocation (Behrens, 2001a, 2001b, 2001c), particularly the introduction of block (or one-line) state grants and more performance-oriented criteria and formula-based procedures. The state of Niedersachsen (Lower Saxony) led the way in this revision of resource allocation, some other states followed, whereas others still practice cameralistic budget procedures or have implemented more flexible allocation mechanisms without completely breaking with traditional allocation forms. Line budgeting is expected to offer greater institutional autonomy, in particular with respect to internal budget allocation, and more effective and transparent cost management. New multi-component models of budget allocation include three major elements in differing proportions: a volume component (e.g. the number of students); a performance and quality component to offer incentives for outstanding achievements in teaching or research; and an objectivesrelated component to stimulate and support innovations in teaching and other strategic goals.

A lively controversy has evolved around the introduction of tuition fees, currently forbidden by federal law, although several states have launched legal protests at the constitutional court. Traditionally, access to (initial) higher education was seen as the right of every applicant who fulfilled the prerequisites, in particular the upper level secondary school examination (the Abitur). Some German states have already established special fees for students who exceed the regular study duration by more than four terms. Others have introduced matriculation or registration fees for each term. More and more politicians and experts predict the general introduction of tuition fees, though only very moderate ones compared with the US. 
Those who oppose tuition fees fear that they are a first step in releasing the state from its funding obligations; that they will unfairly limit access to higher education; and that their side effects will reduce student demand. Proponents of tuition fees cite three main arguments again and again: that higher education is a mixed, partly private, partly public good from which both society and the individual benefit; that they will improve student performance and enable institutions to offer better teaching and counselling; and that there is no other way of financing a permanently expanding system.

Different models of tuition fees have been presented by several organizations or experts: regular fees for a term or a study year; voucher models; so-called study account models; introduction of a special tax for graduates; and other models. Since there is complete disagreement on this issue, the debate continues.

\section{(5) Differentiation}

Deregulation embraces such structural changes as transforming the uniform German higher education system into a more differentiated, competition- and market-oriented system (Schimank \& Winnes, 2001; Teichler, 1997). Institutions can then act more independently to balance out provisions, demand, costs, and benefits. Differentiation can take place along two axes: horizontal and vertical (Gellert, 1995; Teichler, 1996, 1999; Wasser, 1999). Horizontal differentiation rejects the tradition that higher education institutions should provide as many subjects as possible, by and large in the same patterns. Few universities have ever achieved this "ideal." Horizontal differentiation introduces a stronger division of work in programmes according to the particular teaching and research strengths of each institution (profiling).

Vertical differentiation implies a more elaborate ranking order through such indicators as attractiveness, performance, quality, and reputation. Most ranking procedures continue to be controversial due to 
methodological inaccuracies. It is not very likely that any formal hierarchy among universities will be established in Germany. More probably, existing horizontal differences will reinforce informal distinctions in status and reputation among universities and their graduates.

Competition may occur between institutions for the best students or more funding; between students for admission to the best universities; and between academics for enhanced reputation and allocation. Market orientation stimulates competition to improve the quality and effectiveness of higher education. But the demand for greater differentiation runs contrary to the strong forces summarized as "upward academic drift." The Fachhochschulen in particular are fighting for upgraded degrees, extended research opportunities, and other mechanisms to achieve equivalent status with the universities.

\section{(6) Reform of studies}

Studies are typically subdivided into courses which lead to a professional qualification. Traditionally, courses are organized as continuously progressive programmes, with no vertical differentiation between undergraduate and graduate studies with corresponding degrees or a credit point accumulation and transfer system. Flexible programmes, such as distance or part-time studies, play a very minor role in Germany. But the system of studies at German higher education institutions is now undergoing fundamental restructuring processes (Mayer, Daniel, \& Teichler, 2003). There are four main reasons. First, the massification of higher education, and the growing discrepancy between social demand and the traditional organization of studies designed for elite higher education, require qualitative changes in programmes of study. Second, internationalization, in particular the so-called "Bologna-process"- harmonization of study structures in the member states of the European Union-demands far-reaching reforms. Third, there are several home-grown difficulties concerning scholarly quality and effectiveness, in particular high dropout rates and slow throughput. 
Last, German universities have lost international attractiveness to a large extent, especially for foreign students. One reason is the incompatibility of German structures with international standards.

As a part of the "Bologna process," a sequential structure of studies with two successive degrees and a stronger modularization with a credit point system will be established in most European countries. Reform of studies is still controversial in German higher education policy, especially in universities, although European governments and the German federal and state administration want it-and on a fixed time-table. Reforms already implemented or in waiting include:

- introduction of two consecutive cycles of studies analogous to the Bachelor/Master's structure;

- adopting the Bachelor/Master's degrees in different forms;

- compatibility of degrees between different countries;

- introduction of a credit-point system based on the European Credit Accumulation and Transfer System (ECTS);

- modularization of studies;

- promotion of student exchange and mobility;

- establishing procedures of evaluation and intensifying European cooperation in the field of quality assurance;

- extending flexible forms of studying such as part-time or distance studies;

- measures to strengthen the occupation-related studies;

- improved examination regulations;

- improved student orientation and counselling;

- introduction of new media for teaching and instruction;

- reforms in of post-graduate doctoral studies, in particular introduction of graduate schools ("Graduiertenkollegs"); and

- expansion of provisions in the area of continuing higher education to realize the idea of lifelong learning (Schuetze \& Wolter, 2003; Wolter \& Hanft, 2001, Wolter \& Herm et. al., 2003).

These measures have not been fully implemented as yet. For example, the organization of studies on a European model is in infancy. But roughly 1,500 consecutively-organized courses of studies have been introduced in 
Germany. There are two predominant models here: a three-year bachelor's with a two-year master's phase, or a three-and-a-half-year bachelor's with a one-and-a-half year master's phase. Nearly all new courses have been modularized, and most include a credit point system in varying forms. About $50 \%$ have been accredited. On the other hand, many German universities resist consecutive programmes, even as the Fachhochschulen have welcomed it. The main reason for scepticism is widespread fear that new courses and degrees will not be accepted by the labour market and the employment system, which are used in the old degrees.

\section{(7) Quality management}

Evaluation of teaching and instruction (by contrast to evaluation of research) is quite new to Germany, but universities feel obliged to introduce quality assessment under the conditions of a highly competitive market. Of course, the increasing competition for limited public resources is another decisive reason for the introduction of an evaluation and quality management system.

Systematic approaches to evaluation are, in a sense, an integral feature of the overall renewal of higher education. New assessment instruments, especially in teaching and learning, have been established at state level. Few institutions or procedures exist at national level, mostly for research funding or accreditation. Thus, German states practice different types of quality assessment in a multiple and highly diversified system (Bornmann, Mittag, \& Daniel, 2003; Hartwig, 2003; Mayer, Daniel, \& Teichler, 2003). Some states (e.g., Niedersachsen, Bayern, Baden-Württemberg, NordrheinWestfalen) have introduced quality agencies or advisory bodies with standard procedures of internal self-evaluation and external peer review. An Accreditation Council was founded in 1999, responsible to co-ordinate accreditation of new consecutive study programmes.

Although implementation varies among states and institutions and is not yet comprehensive, a new culture of evaluation is asserting itself at German higher education institutions. But a main purpose of evaluation, 
the feedback loop from evaluation to improvement of studies and teaching, has not been achieved.

\section{(8) Access and admission}

Access has become a major element of comprehensive transformation strategy (Wolter \& Lischka, 2001). The central selection and allocation procedures in the case of numerus clausus have provoked growing dissatisfaction. This practice is considered a perfect example of bureaucratic paralysis, primarily because a central agency, the ZVS, is responsible for carrying out this procedure; institutions have only limited rights of their own in the form of certain quotas. Establishment of selective admission procedures within institutional autonomy is regarded as a central element of a competition- and market-oriented organization of higher education. Many policy-makers and professors support an autonomous selection for institutions in order to limit new entrants and curb future expansion of enrollment because, they argue, the massive growth of higher education flies in the face of limited economic demand, meanwhile decisively diminishing the quality of studies and teaching.

Another assertion is that the school leaving certificate, the Abitur, has lost its previous function as a proof of maturity and a good prognosis of future study success. High drop-out rates and continuous extension of the duration of studies argue against any continued validity. According to this argument, selective admission procedures within autonomous institutions would promote institutional differentiation and stimulate competition between applicants.

There are three distinct models for selective admission (Wolter, 2001). The rationalization model is a minimalist, politically less controversial solution: extension of selection rights for courses of studies with total admission restrictions by changing the institutional quota and selection procedures. In the last instance, all available study places would be allocated by the institutions themselves.

The selection model would introduce selective admission in every course of study, thus controlling or even reducing the number of (new) 
students. Precise criteria, requirements, and procedures of such selective admission remain rather unclear. Expert recommendations include formal entrance examinations, checking school achievements and marks, additional ability and personality tests, interviews, essays, and other instruments. Some experts suggest a sequential procedure consisting of Abitur testimonial, test and interview, and other procedures. Some states, in particular Baden-Württemberg and Bayern, emphatically promote this idea, and in both states many institutions or faculties already practice selective admission procedures on the basis of admission quotas.

The allocation model has as its goal neither quantitative restriction of access to higher education nor elimination of the entitlement function of the Abitur. Instead, it aims to establish a competition-oriented multi-stage procedure, so that in the last instance all applicants have study places, but not necessarily at a preferred university. Students would first apply for admission to the university of their choice. The universities would select among applicants according to their profiles, subject requirements, and other standards. Finally those applicants not allocated would be distributed among available study places nation-wide. This "soft" model seeks to optimize access to higher education during allocation, but avoids selective effects. Institutions are autonomous in choosing criteria and instruments. Some supporters of the model reject a regular entrance examination, preferring a simple, highly standardized selection procedure based on the average or subject-related marks of the Abitur.

\section{CONCLUSION}

The German higher education system is changing radically. Compared with other European countries, reform may be late in coming, not only because of recent German history, in particular the re-unification in the year 1990, but also because of German higher education institutions' weak interest in reform. They have, after all, seen themselves as victims rather than active makers of reform. The main direction of this change shows the retreat of the state from a very detailed administrative control system 
to cautious institutionalization of a new triangle of "steering," relying on goal-setting and contract-management at different levels, strengthening the executive and planning functions of the university management, and an elaborate system of output and performance evaluation in research and teaching.

The current state of affairs varies locally. Some reforms have been realized already, some are in preparation or in experimental pilot projects, others still remain in a state of planning or often-controversial discussion. The sixteen German states have taken mildly divergent routes, preferring varying models of this new steering concept or accepting certain elements. Furthermore, the higher education institutions have responded differently; their strategies range from an active policy of promoting reform to reluctance. These facts underline the central importance of institutional policy in reform. According to a recent experts' statement (Stifterverband, 2002), some states are leading in reform (BadenWürttemberg, Hessen, Niedersachsen, and Hamburg) while others are taking a more moderate path in reform policy. The wide range of these activities, plans, and ideas form a modestly systemic approach in reform, but in their broad and radical objectives, they amount to a fundamental transformation of German higher education.

The main direction is the gradual dissolution of the traditional coordination of higher education (in Burton Clark's words) by state authority and academic oligarchy, now substituted-step-by-step-by concepts of steering and organization, elaborated in the framework of new public management and business administration, strengthening competition between and within higher education institutions and increasing the influence of university management (another central instance of coordination Burton Clark [1983] may have overlooked).

The new steering model embraces six key strategies: deregulation of state control in favour of greater autonomy ("institutional empowerment"); re-distribution of influence from the academic oligarchy to the university management ("managerialism"); transformation of the uniform system 
into a more differentiated, competition- and market-oriented system (differentiation and "marketization"); strengthening the specific missions of institutions and improving the quality and flexibility in the provision and organization of studies according to the needs of a diversified body of students ("diversification"); raising the outcome of higher education ("effectivization"); and raising the international competitiveness and reputation of German higher education ("internationalization").

It is difficult to appraise the success of these activities. De facto the balance between the state and higher education has shifted slowly. A pronounced mistrust on the part of the state exists against relatively independent and autonomous institutions in the core areas of state and public responsibility. The state is willing, only to a limited extent, to delegate and transfer state responsibilities to the higher education institutions. Indeed, the shift of weight between state and higher education institutions has been very modest in Germany up to now, compared with other countries.

Even very moderate measures to enable institutions to act more independently are immediately restricted through new and often oversophisticated mechanisms of control. Instead of a leaner organization of responsibilities, the state tends to establish a very expansive and comprehensive system of evaluation and control with new kinds of regular obligations, steering institutions, agencies, committees, and networks which quickly develop their own inherent dynamics. Whenever the institutional scope of disposition increases, an even more complex and elaborate network of control at once limits any new operative autonomy. The state will probably remain the most important actor in the field of higher education policy, developing and implementing new steering instruments, but it is difficult to predict the concrete and detailed role it will play. 


\section{References}

Behrens, T. (2001a). Von der Kameralistik zum Globalhaushalt (From cameralistic to block budget). In P. Pasternack, (Ed.), Flexibilisierung der Hochschulhaushalte (Towards more flexibility in university budgets). Marburg. 25-34.

Behrens, T. (2001b). Der Weg zum Globalhaushalt (Introducing block budgets). In P. Pasternack, (Ed.), Flexibilisierung der Hochschulhaushalte (Towards more flexibility in university budgets). Marburg. 55-67.

Behrens, T. (2001c). Leistungsbezogene Mittelverteilung (Performance dependent allocation). In P. Pasternack, (Ed.), Flexibilisierung der Hochschulhaushalte (Towards more flexibility in university budgets). Marburg. 68-77.

Boockmann, H. (1999). Wissen und Widerstand. Geschichte der deutschen Universität (Knowledge and resistance. History of German universities). Berlin.

Bornmann, L., Mittag, S., \& Daniel, H.-D. (2003). Qualitätssicherung an Hochschulen (Quality assurance in higher education). Essen.

Braun, D., \& Merrien, F.-X. (Eds.). (1999). Towards a new model of governance for universities? A comparative view. London.

Brinckmann, H. (1998). Die neue Freiheit der Universität. Operative Autonomie fiir Lehre und Forschung an Hochschulen (The new freedom of the university. Procedural autonomy for teaching and research). Berlin.

Brueggemeier, M. (2001). Public management. In A. Hanft, (Hrsg.), Grundbegriffe des Hochschulmanagements (Basic terminology in higher education management). Neuwied. 377-383.

Clark, B.R. (1983). The higher education system. Academic organization in cross-national perspective. Los Angeles: Berkeley.

Clark, B.R. (1991). The fragmentation of research, teaching and study. In M. Trow \& T. Nybom, (Eds.), University and Society. London. 101-111.

Fallon, D. (1980). The German university. A heroic ideal in conflict with the modern world. Boulder. 
Gellert, C. (Ed.). (1995). Diversification of European systems of higher education. Frankfurt: Main.

Hartwig, L. (2003). Quality assessment and quality assurance in higher education institutions in Germany. Beiträge zur Hochschulforschung. Vol. 25, 64-82.

Jarausch, K.H. (1991). Universität und Hochschule (Universities and other higher education institutions). In C. Berg, (Ed.). Handbuch der deutschen Bildungsgeschichte (Handbook of the history of education in Germany), Vol. IV. 1870-1918, 313-344.

Luethje, J. (2002). Zielvereinbarungen als Instrument strategischer Steuerung (Target agreements as an instrument of strategic governance). Das Hochschulwesen, Vol. 50, 168-171.

Luethje, J., \& Nickel, S. (Eds.). (2003). Universitätsentwicklung-Strategien, Erfahrungen, Reflexionen (University development-strategies, experiences, reflections). Frankfurt: Main.

Mayer, E., Daniel, H.-D., \& Teichler, U. (Eds.). (2003). Die neue Verantwortung der Hochschulen (The new responsibility of universities). Bonn.

McClelland, C.E. (1980). State, society, and university in Germany 1700-1914. Cambridge.

Mey, D. (2001). New public management. In P. Pasternack, (Ed.), Flexibilisierung der Hochschulhaushalte (Towards more flexibility in university budgets). Marburg, 35-41.

OECD. (1997). Thematic review of the first years of tertiary education-Germany. Paris (unpublished).

OECD. (2003). Education at a glance-OECD indicators 2003. Paris.

Palandt, K. (2002a). Stiftungshochschulen (Higher education institutions as foundations). Das Hochschulwesen, Vol. 50, 202-206.

Palandt, K. (2002b). Zielvereinbarungen zwischen Hochschulen und Landesregierung (Target agreements between university and state government). Das Hochschulwesen, Vol. 50, 162-167. 
Schelsky, H. (1963). Einsamkeit und Freiheit. Idee und Gestalt der deutschen Universität und ihrer Reform (Solitude and freedom. Idea and shape of the German university and its reform). Hamburg.

Schimank, U., \& Winnes, M. (2001). Jenseits von Humboldt? Muster und Entwicklungspfade des Verhältnisses von Forschung und Lehre in verschiedenen europäischen Hochschulsystemen (Beyond Humboldt? Patterns and paths of development in the relationship between teaching and research in different European systems of higher education). In E. Stoelting \& U. Schimank, (Eds.), Die Krise der Universitäten (The crisis of the university). Leviathan. Sonderheft 20. Wiesbaden. 295-326.

Schuetze, H.G., \& Wolter, A. (2003). Higher education, non-traditional students and lifelong learning in industrialized countries. Das Hochschulwesen, Vol.51, 183-189.

Stifterverband für die Deutsche Wissenschaft. (2002). Qualität durch Wettbewerb und Autonomie. Landeshochschulgesetze im Vergleich (Quality through competition and autonomy. Comparison of state higher education laws). Essen.

Teichler, U. (1984). Zum Funktionswandel der Hochschulen (On the changing functions of universities). Pädagogik und Schule in Ost und West, Vol. 32, 4-13.

Teichler, U. (1990). Europäische Hochschulsysteme (European systems of higher education). Frankfurt.

Teichler, U. (1996). Diversity in higher education in Germany: The two-type structure. In V.L. Meek \& L. Goedegebuure, (Eds.), The mockers and mocked: Comparative perspectives on differentiation, convergence and diversity in higher education. Oxford. 117-137.

Teichler, U. (1997). Strukturwandel des Hochschulwesens. Konzepte, internationale Erfahrungen und Entwicklungen in Deutschland (Changing structures of higher education. Concepts, international experiences and German developments). Das Hochschulwesen, Vol. 45, 150-157.

Trow, M. (1974). Problems in the transition from elite to mass higher education. In OECD (Ed.), Policies for higher education. General report. Paris. 51-101. 
Trow, M. (1991). The exceptionalism of American higher education. In M. Trow \& T. Nybom (Eds.). University and society. London. 156-172.

Turner, R.S. (1987). Universitäten (Universities). In K.-E. Jeismann \& P. Lundgreen, (Eds.). Handbuch der deutschen Bildungsgeschichte (Handbook for the history of education in Germany), Vol. III, 1800-1870. München.

Wasser, H. (1999). Diversification in higher education. Kassel.

Wolter, A. (1995). Die Entwicklung der Studiennachfrage in der Bundesrepublik Deutschland (The development of social demand for higher education in Germany). Hannover.

Wolter, A. (1999). Die Transformation der deutschen Universität. Historische Erbschaft und aktuelle Herausforderungen (The transformation of the German university. Historical inheritance and current challenges). In W.-D. Scholz \& H. Schwab, (Eds.). Bildung und Gesellschaft im Wandel (Education and society in a changing world). Oldenburg. 19-60.

Wolter, A. (2001). Von den artes liberales zur Marktsteuerung. Der Übergang von der Schule zur Hochschule im Wandel (From artes liberales to competition. Changes in the transition from school to university). In F.W. Busch \& H. Schwab, (Eds.), Intellektualität und praktische Politik (Intellectuality and practical policy). Oldenburg.

Wolter, A., \& Hanft, A. (2001). Zum Funktionswandel der Hochschulen durch lebenslanges Lernen (Changing functions of higher education through lifelong learning). Oldenburg.

Wolter, A., Herm, B., Koepernik, C., Leuterer, V., Richter, K. (2003) Hochschulen im Weiterbildungsmarkt (Universities at the market of continuing education). Essen.

Wolter, A., \& Lischka, I. (Eds.). (2001). Hochschulzugang im Wandel? Entwicklungen, Reformperspektiven und Alternativen (Changes in access to higher education? Developments, perspectives and alternatives). Weinheim. 


\section{Supplementary Sources}

Braun, D. (2001). Regulierungsmodelle und Machtstrukturen an Universitäten (Models of governance and power structures at universities). In E. Stoelting \& U. Schimank, (Eds.), Die Krise der Universitäten (The crisis of universities). Leviathan. Sonderheft 20. Wiesbaden. 243-264.

Gellert, C. (Ed.). (1999). Innovation and adaption in higher education. The changing conditions of advanced teaching and learning in Europe. London.

Kehm, B. (1999). Higher education in Germany: Developments, problems, perspectives. Bucharest: Wittenberg.

Kogan, M., \& Hanney, S. (Eds.). (2000). Reforming higher education. London.

Peisert, H., \& Framhein, G. (1994). Higher education in Germany. Bonn.

Schwarz, S., \& Teichler, U. (Eds.). (2003). Universität auf dem Prüfstand (The university under scrutiny). Frankfurt: Main.

Teichler, U. (1999). Profilierungspfade der Hochschulen im internationalen Vergleich (Paths of profiling in higher education in an international perspective). In J.-H. Olbertz \& P. Pasternack, (Eds.), Profilbildung-StandardsSelbststeuerung (Profiling-standards-self-governance). Weinheim. 27-38.

Wolter, A., Schnitzer, K. (2000). Two decades of reform in higher education in Europe. 1980 onwards-National description: Germany. EURYDICEThe Information network on education in Europe. Brussels. 